\author{
BARBARA JABEOŃSKA \\ Uniwersytet Jagielloński
}

\title{
O SPOŁECZNYM CHARAKTERZE MUZYKI. SZKIC SOCJOLOGICZNY
}

\section{Wprowadzenie}

Intuicyjnie wszyscy wiemy, że muzyka jest na wskroś zjawiskiem społecznym. Pełni w nim wiele różnorodnych funkcji, stając się niezbywalnym elementem ludzkiej egzystencji. Wiedzieli to już starożytni myśliciele, wskazując na istotną rolę muzyki w społeczeństwie. Platon pisał, że muzyka jest ważnym aspektem edukacji człowieka, podkreślając, iż człowiek dobrze wychowany potrafi śpiewać i pięknie tańczyć [Platon 1958: 314]. Przez muzykę realizowany był zatem proces kształtowania dobrych i cnotliwych obywateli. Podobnie zauważał Arystoteles, pochylając się nad społecznymi walorami muzyki. Jak pisał w VIII księdze Polityki: „jestem tego zdania, że muzykę należy uprawiać nie dla jednego, ale dla wielu pożytecznych celów, bo i dla wykształcenia i dla duchowego oczyszczenia, czyli tzw. katharsis (...), po trzecie zaś i dla wypełnienia czasu spoczynku, dla odprężenia i wytchnienia po pracy" [Arystoteles 1964: 355]. Muzyka jest więc od zamierzchłych czasów postrzegana jako trwały i istotny aspekt życia społecznego. Dziś zaś - jak zauważa Allan Bloom - „żyjemy w epoce muzyki i stanów duszy, które jej towarzyszą" [Bloom 1987: 78]. Nie sposób więc nie zwrócić uwagi na społeczne aspekty muzyki, czyli na to, co faktycznie ją konstytuuje.

W swoim artykule chciałabym uzasadnić, jakie czynniki rzeczywiście mówią nam o tym, że muzyka ma charakter społeczny. Można oczywiście od razu stwierdzić, że bez ludzi muzyka nie miałaby szansy na zaistnienie, gdyż to w ich działalności muzycznej (zarówno twórczej, jak i odtwórczej i odbiorczej) jest tworzona i reprodukowana. Ktoś inny mógłby jednak powiedzieć, że przecież muzyka może posiadać charakter całkowicie autoteliczny, będąc bytem samym dla siebie, nie potrzebując odbiorcy i społecznej przestrzeni. Zawsze jednak tworzona jest przez człowieka, niezależnie 
czy „do szuflady”, czy też dla szerokiego audytorium. Powstaje również niezależnie od tego, czy odbiorca jest bytem „realnym”, czy też „idealnym” w rozumieniu Władysława Stróżewskiego [1983: 216]. Niewątpliwie muzyka jest medium, które zapośrednicza ludzką komunikację. Jak pisał Alphons Silbermann, autor kultowej książki Sociology of Music, „muzyka jest zasadniczo zjawiskiem społecznym, z uwagi na to, że jest wytworem ludzkiej działalności oraz formą komunikacji pomiędzy kompozytorem, interpretatorem oraz słuchaczem" [Silbermann 1963: 38]. Z kolei znakomity badacz zjawisk społeczno-muzycznych, Simon Frith napisał: „muzyka to uporządkowana struktura dźwięków spośród ogromnej wielości bardziej lub mniej nieuporządkowanych zjawisk słuchowych” [Frith 2011: 134]. Aby jednak zjawiska te stały się dla ludzi znaczące, musi zaistnieć szereg czynników, które powodują, że staje się ona elementem świata społecznego.

Co zatem decyduje o tym, że mówimy o społecznym wymiarze muzyki, i o tym, że jest ona wytworem społecznym? Chciałabym omówić sześć takich elementów, które silnie wskazują na społeczny charakter muzyki. Po pierwsze, muzyka jest elementem kultury, w szczególności zaś w węższym rozumieniu - elementem kultury symbolicznej. Tym samym jest ona nośnikiem określonych znaczeń, przekazując treści i zapośredniczając międzyludzką komunikację. Po drugie, muzyka jest relacją społeczną, gdyż wokół niej tworzą się więzi, budują interakcje, powstaje siatka wzajemnie zorientowanych na siebie działań aktorów społecznych. Po trzecie, muzyka jest formą kontekstu społecznego, z którym ściśle wiążą się określone reguły normatywne i społecznie negocjowane wzory działania. Osadzone są one w danym porządku społeczno-kulturowym, wskazując nam, jak zachowywać się w odpowiednich sytuacjach związanych z tworzeniem, odtwarzaniem i odbiorem muzyki. Po czwarte, muzyka jest elementem struktury społecznej - jest zarówno tym, co strukturyzuje społeczeństwo, jak i czymś, co jest strukturyzowane w procesie działań ludzkich zorientowanych na sztukę dźwięków. Muzyka jest zatem zarówno determinowana przez strukturę społeczną, jak i stanowi element jej odtwarzania i reprodukowania. Po piąte, muzyka jest ściśle powiązana ze zmianą społeczną. Jest ona uwikłana w nieuchronny proces dynamicznych przemian społeczno-kulturowych, następujących cyklicznie po sobie. I po szóste, muzyka pełni istotne społecznie funkcje, począwszy od funkcji komunikacyjnej, tożsamościowej, integracyjnej, poprzez funkcje użytkowe i ludyczne, a skończywszy na funkcji ekonomicznej, czy też politycznej. Warto przyglądnąć się kolejno wszystkim tym wymienionym kwestiom. 


\section{Muzyka jako element kultury symbolicznej i zestaw znaczeń}

Pierwszy z omawianych wymiarów ma charakter metaproblematyczny. To bowiem w wymiarze kulturowym ogniskują się wszystkie pozostałe, omawiane poniżej, społeczne aspekty muzyki. Odwołując się do Antoniny Kłoskowskiej można powiedzieć, iż muzyka - podobnie jak sztuka w ogólności - pojmowana jest jako wytwór ludzkiej działalności, stanowiąc tym samym jeden z podstawowych wymiarów kultury symbolicznej [Kłoskowska 1991]. Jak zauważa autorka:

na kulturę w węższym rozumieniu składają się działania i wytwory o charakterze symbolicznym. Symbolicznymi nazywa się przy tym czynności ludzkie posiadające znaczenie. Proces symbolizowania to czynność polegająca na wytwarzaniu i komunikowaniu albo odbieraniu i interpretowaniu znaków właściwych. Procesem takim jest zwłaszcza mowa, wiedza i sztuka [Kłoskowska 1972: 20].

Jak argumentuje Adam Grzeliński [2012: 22], symboliczna moc dzieła jest jego pierwotną funkcją, gdyż symbol pozbawiony jest arbitralności, choć oczywiście podporządkowany jest pewnej konwencji. Jest też czymś, co odznacza się niedowolnością i niezastępowalnością [Grzeliński 2012: 22]. Dopiero wtórnie dziełu przypisywane są znaczenia, wyrażone przez system określonych treści.

Muzyka jest zatem jednym $\mathrm{z}$ istotnych wytworów ludzkiej działalności, posiadającym określone znaczenia. Innymi słowy, jest nośnikiem pewnych treści, symboli i znaczeń, które podlegają nieustannej interpretacji w społecznym obiegu. To bowiem ludzie przypisują muzyce określone treści, wiążą z nią pewne sensy i interpretują w danym kontekście społeczno-kulturowym. Można powiedzieć, za Wendy Griswold, że muzyka - podobnie jak szerzej pojęta sztuka - jest obiektem kulturowym. Obiekt kulturowy to „zestaw podzielanych znaczeń wyrażonych w pewnej formie. Innymi słowy, to obdarzona społecznym znaczeniem forma wyrazu, którą można usłyszeć, zobaczyć, dotknąć lub wypowiedzieć” [Griswold 2013: 43]. I właśnie owe znaczenia decydują o tym, że jakiś wytwór ludzkiej działalności (a jest nim również muzyka) jest dla ludzi istotny. W tym sensie możemy powiedzieć, że muzyka to znaczący układ dźwięków, gdyż to ludzie nadają im określone treści. Jak bowiem zauważają Dasilva, Blasi i Dees, muzyka jest konstruktem społecznym i określonym typem mentalności [Dasilva, Blasi, Dees 1984: 3]. Tak jak ludzie myślą w określonych językach i w nich się porozumiewają, tak i komunikują się za pomocą muzyki. Pytanie jednak, jakie są to treści i w jakim sensie możemy mówić o muzycznym języku? 
Ta kwestia wydaje się znacznie bardziej problematyczna i wykracza poza zarysowaną tu tematykę. O językowym charakterze muzyki piszę jednak w innym miejscu [zob. Jabłońska 2014]. Warto tu jedynie zaznaczyć, iż płaszczyzn komunikowania za pomocą muzyki może być wiele, zaś jedną z najistotniejszych wydaje się płaszczyzna emocjonalno-ilustracyjna. Muzyka bowiem porusza ludzkie serca i ludzką wyobraźnię, dostarczając estetycznych przeżyć. Co więcej, znaczenia, jakie ze sobą niesie, warunkowane są określonym kontekstem społeczno-kulturowym, a równocześnie mają one charakter uniwersalny. Muzyka jest bowiem jedynym tak powszechnie zrozumiałym kodem znaczeń, które mogą być odpowiednio odszyfrowywane pod każdą szerokością geograficzną. Równocześnie zaś jest zestawem znaczeń silnie splecionym $z$ tradycją muzyczną danego społeczeństwa, jego pamięcią społeczno-muzyczną, tradycjami, zwyczajami, normami, regułami tworzenia i słuchania.

\section{Muzyka jako relacja społeczna}

O społecznym charakterze muzyki decyduje też to, że jest ona sposobem zapośredniczania międzyludzkich relacji, czy - używając bardziej precyzyjnego określenia - międzyludzkich interakcji. Definicja interakcji, rozumiana tu jako wzajemnie zorientowane na siebie działania aktorów, w których każdy $\mathrm{z}$ nich reaguje na to, co czyni ten drugi, równocześnie modyfikując swoje działania [zob. Sztompka 2002], najlepiej oddaje istotę omawianego tu zagadnienia. Muzyka, pojmowana jako dzieło sztuki, jest więc elementem zapośredniczającym komunikację pomiędzy ludźmi. Ciekawie na ten temat piszą choćby psychologowie muzyki, którzy zwracają uwagę na wzajemne oddziaływania artystów i publiczności podczas koncertów na żywo. Jak zauważa Karolina Pietras, „wykonywanie muzyki na żywo przy udziale publiczności można opisać w kategoriach wydarzenia społecznego. $Z$ tej perspektywy koncert jest specyficznym, interaktywnym procesem komunikacji z grupowym odbiorcą (widownią), a zachodzące w nim zjawiska podlegają wpływowi społecznemu i grupowym procesom" [Pietras 2015: 41].

Innymi słowy, jak podkreślał wielki polski socjolog, Stanisław Ossowski, dzieło sztuki jest ośrodkiem stosunków społecznych [Ossowski 1966: 366]. Muzyka umożliwia więc porozumienie pomiędzy uczestnikami procesu komunikacji, tworząc relację między nadawcą i odbiorcą. Zarówno proces tworzenia, odtwarzania, jak i odbioru sztuki jest procesem społecznym, interakcyjnym i wspólnotowym. Dzieło sztuki uosabia - jak podkreślał 
Ossowski - „niewidzialną” wspólnotę ludzką. Przez dzieło sztuki możliwe staje się też - zdaniem uczonego - „kształtowanie harmonii współżycia” oraz „uczuciowe jednoczenie ludzi” [Ossowski 1966: 346]. Dzięki obcowaniu ze sztuką (w tym z muzyką) możliwe jest budowanie więzi społecznych, często ponad ustalonymi podziałami. Jak zauważał Ossowski, odnosząc się do więziotwórczej funkcji dzieła sztuki, „te wszystkie stosunki, które się wokół niego oplatają, mają specjalny charakter. Dzieło sztuki może rzucać pomost poprzez stulecia, poprzez lądy i morza" [Ossowski 1966: 345]. Oznacza to, że sztuka (a zatem i muzyka) pozwala na nawiązanie relacji pomiędzy najbardziej odległymi od siebie jednostkami (zarówno pod względem geograficznym, jak i psychologicznym, społecznym i kulturowym).

O więziotwórczej i spajającej społeczeństwo mocy muzyki pisał też inny wielki klasyk myśli socjologicznej, Georg Simmel, który jako jeden z pierwszych „ojców socjologii” posługiwał się pojęciem interakcji, jak również interesował się najróżniejszymi jej przejawami, w tym w odniesieniu do życia muzycznego ludzi. Dla Simmla muzyka miała niezwykle silny walor komunikacyjny i tożsamościotwórczy. Simmlowskie analizy koncentrują się bowiem między innymi na badaniu roli muzyki w życiu określonych grup etnicznych. Jak zauważa interpretator myśli Simmla, K. Peter Etzkorn, niemiecki uczony wyraźnie wskazuje na „istotną zależność pomiędzy muzyką etniczną i psychologią grupy społecznej, w której praktykowana jest owa muzyka" [Etzkorn 1964: 102]. Traktuje on więc muzykę jako jeden z aspektów relacji społecznych [Etzkorn 1964], ponieważ przez dźwięki możliwe jest strukturowanie i przekształcanie owych relacji. Ważną rolę u Simmla pełni zatem ten typ muzyki, który wiąże się z podtrzymywaniem tożsamości grupy, w tym tożsamości o charakterze narodowym.

Szczególnie interesujący socjologicznie jest przebieg owych relacji, czyli prześledzenie owej struktury, z której utkane są interakcje wokół muzyki. Nie sposób nie odwołać się w tym miejscu do Alfreda Schütza, znakomitego przedstawiciela socjologii fenomenologicznej, dla którego muzyka była znaczącym działaniem, którym ludzie przypisują określone treści, gesty, symbole [Schütz 2008]. Główną osią rozważań Schütza jest „szczególny charakter wszystkich interakcji społecznych wiążących się z procesem muzycznym" [Schütz 2008: 225]. Działania aktorów podejmowane w procesie muzycznym są więc na siebie wzajemnie zorientowane, jak również poparte odpowiednim zasobem wiedzy muzycznej, oraz - co niezwykle ważne osadzone w szerszym społeczno-kulturowym kontekście, co ostatecznie pozwala wypełnić warunek intersubiektywnej komunikowalności. Przez wzajemnie zorientowane na siebie działania aktorów osadzonych w danych 
warunkach społeczno-kulturowych i wyposażonych w odpowiednią wiedzę i kompetencje (lub szerzej - kulturę muzyczną), jak również przez zestrojenie ich strumieni świadomości w czasie wewnętrznym, możliwa staje się muzyczna komunikacja odbywająca się na poziomie pozasematycznym. Dzięki temu możliwe jest konstruowanie relacji „my”, której podstawę stanowi tak zwany mechanizm idealizacyjny przekładalności perspektyw.

Schütz zwraca uwagę w szczególności na rytuały interakcyjne, które pozwalają na wzajemną synchronizację działań, tak niezbędnych podczas wykonywania czy też odbioru muzyki. Aby bowiem można było wykonać dany utwór, jego odtwórcy muszą się wzajemnie rozumieć, co możliwe jest przede wszystkim dzięki znaczącym gestom. Jak zauważa Schütz:

wspólne tworzenie muzyki ma miejsce w obrębie prawdziwej relacji „twarzą w twarz" - o ile wykonawcy podzielają nie tylko pewien wycinek czasu, lecz również obszar przestrzeni. Wyraz twarzy „drugiego”, jego gesty w trakcie gry na instrumencie, czyli krótko mówiąc wszystkie działania związane z wykonaniem utworu zachodzą w czasie zewnętrznym i mogą zostać natychmiast uchwycone przez partnera [Schütz 2008: 238].

Podążając za logiką myślenia Schütza można dodać, iż podobne rytuały interakcyjne związane są również z relacją między wykonawcą i słuchaczem, podzielającymi ten sam czas i tą samą przestrzeń.

\section{Muzyka jako społeczny kontekst i reguły normatywne}

Mając na względzie wszystko to, co zostało powiedziane do tej pory, dochodzimy do trzeciej istotnej cechy, która dobitnie mówi nam o społecznym charakterze muzyki. Sztuka dźwięków wiąże się bowiem ściśle z określonymi regułami normatywnymi, które nabierają sensu i znaczenia $\mathrm{w}$ danym kontekście. Będą one zatem regulować przebieg interakcji, podpowiadając, w jaki sposób zachować się w danej sytuacji społeczno-muzycznej (np. w operze, w kościele, na imprezie disco-polo, na rodzinnej biesiadzie muzycznej), od jakich zaś działań się powstrzymać. Bez owych reguł nie byłoby więc możliwe zarówno poruszanie się w świecie muzycznym, jak i odpowiednie zrozumienie działań innych aktorów. Innymi słowy, nie jest możliwe ani tworzenie, ani też słuchanie muzyki w oderwaniu od jej społecznego kontekstu - czy posługując się terminologią zaproponowaną przez Ola Stockfelta - w oderwaniu od tak zwanej „sytuacji słuchania” 
[Stockfelt 2010]. Jak słusznie zauważa Simon Frith, „potrzebujemy znajomości nie tylko form muzycznych, lecz także reguł zachowania w sytuacjach związanych z muzyką" [Frith 2011: 340]. Kluczowe jest jednak pytanie, skąd wiemy jak zachowywać się w określonych kontekstach społecznych powiązanych z muzyką? Odpowiedź jest prosta - decyduje o tym cały skomplikowany mechanizm nabywania określonych umiejętności i kompetencji wdrażanych $\mathrm{w}$ procesie socjalizacji. Bourdieu nazywa to „habitusem”. Każda epoka ma jednak swoje narzędzia socjalizacji do odbioru muzyki i wyznaczania reguł - „sposobów słuchania”. Wraz z owymi regułami zmienia się sposób zachowania aktorów społecznych. Maria Ossowska pisze o sposobach wdrażania i przyswajania społecznych norm, co nie zawsze jest tożsame $\mathrm{z}$ ich przestrzeganiem [zob. Ossowska 2007: 299]. Zderzenie alternatywnych wzorów może powodować zaburzenie interakcji w określonych kontekstach społeczno-muzycznych. Na myśl przychodzi przypadek Ignacego Jana Paderewskiego, który - będąc na tournée w Ameryce Południowej - nie mógł zaakceptować faktu, iż podczas tamtejszych koncertów panował zwyczajowo głośny szum rozmów słuchaczy. Obserwując tamtejsze życie muzyczne, tak oto opowiadał w swoich Pamiętnikach: „w czasie koncertu wszyscy słuchacze rozmawiali głośno i bez przerwy. A wie pani, dlaczego tak się działo i dlaczego tolerowano tę nieustanną rozmowę, tak lekceważącą w stosunku do artysty? Z ich punktu widzenia odpowiedź była prosta - taka to już tradycja hiszpańska!" [Paderewski 1984: 288]. Sam jednak nie zgodził się, by podczas jego koncertu ktokolwiek rozmawiał. Zagroził bowiem zerwaniem kontraktu i przerwaniem występów w Buenos Aires, jeśli publiczność zaczęłaby rozmawiać podczas jego gry. I rzeczywiście tak się nie stało, publiczność słuchała występów Paderewskiego w milczeniu, niemniej jednak poprzedzone było to swoistą „akcją edukacyjną" organizatorów koncertu w domach melomanów. Jak pisał Paderewski w swoich Pamiętnikach:

Zawdzięczałem to madame de Castex, która (...) chodziła od domu do domu, prowadząc istną kampanię. Wiele lat później usłyszałem od jej przyjaciółki (...), że pani de Castex zapewniała ją wówczas, iż na wypadek rozmów podczas koncertu na pewno zerwę kontrakt, co wywołałoby duży skandal w Buenos Aires. „Stalibyśmy się - mówiła - pośmiewiskiem całego muzykalnego świata, gdyż wkrótce wszyscy dowiedzieliby się o tym, że Paderewski nie chciał u nas koncertować. Buenos Aires zyskałoby opinię niemuzykalnego, mało kulturalnego i nieuprzejmego miasta” [Paderewski 1984: 290]. 
Wspomniany przykład jest doskonałą ilustracją omawianej tu kwestii kulturowo i społecznie wyznaczanych wzorców postępowania, akceptowanych w danym czasie historycznym i w danym kręgu kulturowym. Zderzenie owych wzorców może prowadzić do zakłóceń interakcyjnych, bądź też może powodować konieczność wypracowania na nowo pewnych sposobów działania. Niemniej jednak, aktorzy społeczni zazwyczaj doskonale potrafią rozpoznać dane sytuacje słuchania, wiedząc, w jaki sposób się zachowywać. W dobie najnowszych technologii i rozwoju nowych mediów reguły te wymagają jednak na nowo wypracowania. Muzyka wykroczyła bowiem poza tradycyjne konteksty (sale koncertowe, obiekty sakralne), towarzysząc człowiekowi nieomal wszędzie. A zatem, jak zauważa Howard S. Becker, aby zrozumieć dzieło sztuki oraz jego odbiór, musimy „zrozumieć instytucjonalne i dyskursywne procesy (świat sztuki), w ramach których jest ono interpretowane jako dzieło sztuki, jako obiekt, względem którego ze społecznego punktu widzenia stosowany jest określony rodzaj estetycznej reakcji” [za: Frith 2011: 46].

\section{Muzyka jako element struktury społecznej}

Kolejnym - czwartym już - i niezwykle istotnym wyznacznikiem społecznego charakteru muzyki jest jej sprzężenie ze strukturalnym wymiarem życia społecznego. Szczególnie wyraźnie widoczne było to w czasach, w których muzyka nie miała tak powszechnego i egalitarnego charakteru, będąc dostępną wyłącznie dla określonych grup społecznych. Przed epoką medialną i rozwojem nowych technologii była ona osiągalna tylko w określonych kontekstach społecznych (najczęściej była to muzyka na żywo podczas różnorodnych koncertów i wydarzeń muzycznych [zob. Kofin 2012]). Oznaczało to, że konsumować ją mogli na szerszą skalę jedynie przedstawiciele klas wyższych, uczestnicząc w życiu kulturalnym - czy szerzej pojętej kulturze wyższej. Widoczne też były mocniej dysproporcje jeśli chodzi o gust muzyczny. Kwestia gustu muzycznego sama w sobie jest przykładem strukturalnego uwikłania muzyki, gdyż gust przypisywany był od zawsze przedstawicielom określonych klas społecznych. Na myśl przychodzi tu na przykład rozróżnienie na gust „barbarzyński” i gust „czysty” w klasyfikacji Pierre’a Bourdieu [2005]. Dla Bourdieu muzyka była bowiem jedną z praktyk dystynktywnych, pozwalających na wyznaczanie pozycji w strukturze społecznej i akcentowanie klasowej odrębności. Jak podkreślał francuski myśliciel, „gusta (to znaczy przejawiane preferencje) stanowią prak- 
tyczne potwierdzenie nieuniknionej różnicy" [Kofin 2012: 74-75]. Gust jest więc systemem klasyfikacji ściśle powiązanym ze strukturą klasową. Zdaniem francuskiego myśliciela, „nic nie daje takiej możliwości podkreślenia «klasy» jakiejś osoby i takiej podstawy do uklasowienia, jak gusta w dziedzinie muzyki" [Kofin 2012: 27]. Nie ma więc chyba - jak dodaje francuski myśliciel - bardziej klasyfikującej praktyki, niż ta powiązana z muzyczną aktywnością, muzycznym gustem, czy grą na „szlachetnym instrumencie" [Kofin 2012]. Jak zauważa Simon Frith, odnosząc się do Bourdieu w swojej słynnej pracy Sceniczne rytuały. O wartości muzyki popularnej, „kulturowa granica pomiędzy tym, co wysokie i niskie, była częściowo definiowana przez wybory dokonywane przez ludzi (kompozytorów, wykonawców, słuchaczy) we wspólnym muzycznym kontekście. Tylko w kontekście tego rodzaju wyborów (...) oczywiste może się stać społeczne znaczenie osądu" [Frith 2011: 35].

Niemniej jednak, postępująca mediatyzacja życia społecznego, najpierw na poziomie analogowym, później zaś cyfrowym, przyniosła w tym zakresie duże zmiany. O dostępności do sztuki wyższej nie decyduje już bowiem tak mocno status społeczny i zasoby symboliczne oraz ekonomiczne. Wraz z digitalizacją audiosfery spełnił się postulat Karola Szymanowskiego, który w czasach przedwojennych (nie wiedząc wówczas o rewolucji medialnej, jaka kiedyś czeka ludzkość) pisał o demokratyzującej sile muzyki [Szymanowski 1949]. Oczywiście społeczeństwo wciąż różnicowane jest ze względu na muzyczny gust, który ma w znacznej mierze podłoże strukturalno-klasowe, granice te jednak są znacznie bardziej płynne i niedookreślone. Trudno dziś bowiem wyznaczać trwałe i jednoznaczne linie demarkacyjne pomiędzy „elitami” i „masami”, konsumującymi sztukę pięknych dźwięków. Powstają raczej w ich miejsce hybrydowe formy tworzenia i odbioru muzyki, tak samo jak hybrydowe są także formy ich dystrybuowania.

Inną kwestią, która związana jest ze strukturalnym wymiarem muzyki, jest miejsce artystów-muzyków w społeczeństwie i pełnione przez nich społeczne role. Rola społeczna jest bowiem integralnym elementem struktury społecznej i pozycji społecznych, jakie zajmują weń działające jednostki. Na temat miejsca i roli artysty muzyka w strukturze społecznej można rozpisywać się na wielu dziesiątkach stron, stąd też ramy niniejszego opracowania nie pozwalają na dogłębne opisanie tej problematyki. Warto jednak wskazać na kilka istotnych kwestii. Wiążą się one z nieustannym i postępującym procesem przemian ról zawodowych muzyków na przestrzeni wieków. Tak jak zmienia się charakter struktury społecznej, tak i zmieniają się praktyki społeczno-muzyczne działających weń aktorów. 


\section{Muzyka jako zmiana społeczna}

Kolejną ważną kwestią, która świadczy o społecznym charakterze muzyki jest procesualność i dynamika przemian życia społeczno-muzycznego ludzi na przestrzeni wieków. Jest to zupełnie naturalna cecha, skoro muzyka stanowi element kultury symbolicznej oraz jest tworzona i reprodukowana w procesie ludzkich działań. Tak jak zmienia się życie ludzkie na osi czasu, tak też przemianom ulegają praktyki muzyczne. Odznaczają się one zatem zarówno pewnym komponentem strukturalnym (w który wpisana jest ciągłość i trwałość owych praktyk), jak i cechują się dynamiką i zmiennością (w którą wpisana jest płynność i fluktuacja). Nie ma tu znów miejsca, by opisywać całe dzieje przemian życia muzycznego ludzi. Pozostawiam to innym ekspertom, w szczególności zaś muzykologom. Tu chciałabym jednak zaakcentować kilka przykładowych kwestii, które wskazują nam, jak mocno muzyka powiązana jest z procesem przemian społecznych, czy - szerzej ujmując - ze zmianą społeczną. Może bowiem jest tak, że muzyka ulega nieustannym, cyklicznym zmianom na przestrzeni wieków, a może jednak zmiana ta ma charakter linearny?

W pierwszym przypadku, a więc w odniesieniu do zmiany cyklicznej, na myśl znów przychodzi konkretny przykład, stanowiący doskonałą ilustrację dla podjętych tu rozważań. Jest to monumentalne dzieło klasyka myśli socjologicznej, Pitirima Sorokina, Social and Cultural Dynamics [Sorokin 1991], w której opisany został mechanizm cyklicznych i naprzemiennych faz rozwoju całej sztuki, w tym także muzyki. Jak zauważa K. Peter Etzkorn, Sorokin jest „pierwszym socjologiem, który włączył muzykę do systematycznej (...) analizy socjologicznych zagadnień związanych ze społeczną i kulturową integracją" [Etzkorn 1973: 27]. Posługując się modelem Sorokina, można powiedzieć, że zmiana w obrębie systemu społeczno-kulturowego (a także i muzycznego) polega na cyklicznym, naprzemiennym i długoterminowym następowaniu po sobie faz - ideacyjnej i zmysłowej, z włączeniem $\mathrm{w}$ to fazy przejściowej, czyli idealistycznej, która rozdziela te dwie pierwsze. Każda z nich jest odzwierciedleniem swoistej „mentalności kulturowej”, dominującej w danej epoce. Muzyka ideacyjna i zmysłowa są jak ogień i woda - stanowią przeciwieństwa. Ta pierwsza przekazuje pewne idee, ale niekoniecznie musi dostarczać słuchowej przyjemności. Jest raczej formą symboliczną, pozwalającą na doskonalenie wewnętrzne jednostki. Przykładem może tu być chorał gregoriański. Ta druga zaś (czyli zmysłowa), dostarcza 
w pierwszej kolejności przyjemności słuchowej, jest piękna i hedonistyczna. Przykładem może być tu muzyka romantyczna. Zdaniem Sorokina, fazy te następują cyklicznie po sobie, przechodząc przez fazę przejściową.

Druga koncepcja zmiany muzyki w obrębie systemu społecznego to zmiana linearna. Ma ona zatem charakter jednokierunkowy, przechodząc od jednej fazy, do kolejnej. Fazy te mogą być związane $\mathrm{z}$ doskonaleniem stanów poprzednich. Jak zauważa Piotr Sztompka, w przypadku zmiany kierunkowej, żadna faza procesu nie jest identyczna z poprzednimi, co oznacza nieodwracalność zmiany [Sztompka 2010: 439]. Jeśli chodzi o przykład tak rozumianej zmiany, to na myśl przychodzą tu dwa przykłady. Pierwszy z nich to proces racjonalizowania się praktyk ludzkich związanych z muzyką, jaki rozgrywał się (i wciąż się rozgrywa) na przestrzeni dziejów, i który opisany został doskonale przez Maxa Webera w książce The Rational and Social Foundations of Music [Weber 2009]. Niemiecki myśliciel poszukiwał przykładów świadczących o procesie racjonalizowania się muzyki, sięgając do tradycji średniowiecznego monastycyzmu. Główną tezą Webera było przekonanie, iż muzyka europejska stopniowo ewoluowała od form irracjonalnych i całkowicie mistycznych do tych bardziej racjonalnych i standaryzowanych. To, na co w szczególności zwracał uwagę niemiecki uczony, to między innymi kwestia standaryzacji notacji muzycznej, ewolucja harmonii, wykształcenie się muzyki polifonicznej, ukonstytuowanie się składu zespołów instrumentalnych i orkiestr, a także wyznaczanie jednolitych standardów budowy instrumentów muzycznych. Bazą tych wszystkich przemyśleń była dla Webera matematyczna koncepcja muzyki, powiązana $\mathrm{z}$ uwagami co do procesów racjonalizacji kultury Zachodu. W tak rozumianym procesie zmiany kierunkowej muzyki szczególnie istotne było wykształcenie się zapisu nutowego. Jak pisał Weber: „jeśli zapytamy o szczególne uwarunkowania zachodniego rozwoju muzycznego, to należy do nich przede wszystkim wynalazek naszego nowoczesnego zapisu nutowego" [Weber 2013: 16]. Zapis ten ulegał stopniowej standaryzacji. Zalążkiem i impulsem do rozwoju tak rozumianego procesu racjonalizacji były bowiem średniowieczne, europejskie klasztory. Weber starał się pokazać, iż to mnisi i zakonnicy przyczynili się znacząco do standaryzacji notacji muzycznej [Turley 2001: 634]. Podobnie jak zapis nutowy, także standaryzacja reguł harmonii muzycznej była istotnym elementem racjonalizowania się europejskiej muzyki, co drobiazgowo opisywał Weber. Zdaniem Dirka Kaeslera: 
Max Weber śledził tę swoją myśl prowadząc porównawcze studia historyczne obejmujące zarówno pierwotne i starożytne studia rozwoju, jak i czasy nowożytne. Główny wynik tych badań polegał na ustaleniu, że zasadę prostego interwału między dźwiękami zastąpiła „racjonalna” zasada harmonii akordów. Rozwój ten Weber interpretował jako przejaw racjonalnej mentalności społeczeństwa zachodniego [Kaesler 2010: 222].

Jak podkreślał Weber:

nasza muzyka, której harmonika opiera się na strukturze akordowej, racjonalizuje materiał dźwiękowy przez arytmetyczny, czyli harmoniczny podział oktaw na kwinty i kwarty, a następnie, odkładając kwartę na stronę, dzieli kwintę na tercję wielką i małą ([w proporcji jak] 4/5x5/0=2/3), wielką tercję na cały ton mały i wielki $(8 / 9 \times 9 / 10=4 / 5)$, tercję małą na cały ton wielki i półton wielki $(8 / 9 \times 15 / 16=5 / 6)$, a cały ton mały na półtony wielki i mały (15/16x24/25=9/10), [Weber 2013: 11].

Jest to zatem przykład ewoluowania muzyki w stronę coraz bardziej racjonalnych, wystandaryzowanych form, właściwych kulturze europejskiej, co stanowi przejaw dynamicznego rozwoju sztuki dźwięków na przestrzeni wieków, jak również przejaw ludzkiej działalności powiązanej z muzyką.

Drugi przykład, pokazujący linearny i kierunkowy charakter zmiany społecznej w obrębie życia muzycznego ludzi dotyka problematyki rynku muzycznego i biznesu muzycznego. Tu również widać nieustanną zmianę praktyk muzycznych związanych zarówno z tworzeniem, dystrybuowaniem, jak i odbiorem muzyki. Doskonałym case study zmiany kulturowej w obrębie muzycznych praktyk jest studium przemian muzyki country, opracowane kilka dekad temu przez Richarda Petersona i opisane w tekście The Production of Cultural Change: The Case of Contemporary Country Music [Peterson 1978]. Jak pokazuje autor, przemiany w obrębie jednego gatunku muzycznego mogą pociągnąć za sobą zmianę w całym przemyśle muzycznym. Pojawienie się bowiem w latach pięćdziesiatych XX wieku innego gatunku muzycznego, czyli rock-and-rolla (a wraz z nim postaci Elvisa Presleya) istotnie wpłynęło na kształt i charakter dotychczas mocno ugruntowanej w tradycji amerykańskiej muzyki country. „Zagrożenie” ze strony dynamicznie rozwijającej się kultury rock-and-rollowej wpłynęło nie tylko na integrację środowiska country (powstanie zrzeszenia Country Music Associatnion, tworzenie stacji radiowych grających country), ale też na zmianę brzmienia tego drugiego gatunku muzyki. Aby bowiem utrzymała ona swoją mocną pozycję wśród słuchaczy, twórcy country zaczęli - paradoksalnie (broniąc się przed konkurencją) - przemycać w swojej muzyce elementy rockowe, tym samym wygładzając nieco chropowaty 
charakter tradycyjnej muzyki kowbojskiej. Tym samym country coraz bardziej upodobniała się do konkurencyjnej wówczas muzyki, zyskując rockowe brzmienie. W ten sposób Peterson opisał specyfikę zmiany kulturowej, w której motorem napędowym stały się zmieniające się potrzeby słuchaczy [Peterson 1978: 293].

Współcześnie przemiany rynku muzycznego są jeszcze bardziej widoczne, wiążąc się z udogodnieniami technologicznymi i możliwościami, jakie dają nam nowe media. Wydaje się, że zmiana postępuje w stronę jak najdoskonalszej racjonalności rynku muzycznego, choć oczywiście widoczne są również pewne „wahnięcia” w tył, co jednak i tak powiązane jest z nowymi sposobami doświadczania muzyki. Przykładem może być tu płyta winylowa, przeżywająca wyraźnie swój renesans w ostatnich latach. Trend ten powiązany jest jednak nie tyle $\mathrm{z}$ racjonalnością ekonomiczną, co raczej ze stylem życia i koneserstwem muzyki.

\section{Muzyka jako element funkcjonalny w społeczeństwie}

Truizmem jest stwierdzenie, że muzyka pełni w społeczeństwie wiele ważnych funkcji. Ten ostatni aspekt społecznego wymiaru muzyki, o którym chciałabym tu wspomnieć, to niejako klamra spinająca wszystkie dotychczas poruszane kwestie. Funkcja rozumiana jest tutaj jako zinstytucjonalizowany sposób zaspokajania społecznych potrzeb. Muzyka realizuje owe potrzeby, począwszy od funkcji integracyjnej i komunikacyjnej, poprzez funkcje tożsamościotwórcze, ludyczne, eskapiczne, użytkowe, terapeutyczne, a skończywszy na funkcjach politycznych, ekonomicznych, edukacyjnych, czy też religijnych, by wymienić tylko te najważniejsze [zob. Jabłońska 2014].

Należy podkreślić, iż nie sposób omówić tu dokładnie i wyczerpująco wielości i różnorodności owych funkcji. Chciałabym jednak zwrócić uwagę na kilka istotnych kwestii, które wiążą się z funkcjonalnym aspektem muzyki. Po pierwsze, muzyka zaspokaja potrzebę bycia we wspólnocie, tworzenia więzi społecznych, budowania kategorii „my”. Doskonałym przykładem są tu subkultury muzyczne, w których nie tylko określana jest tożsamość społeczno-muzyczna jej członków, ale też realizowana jest potrzeba przynależności do grupy i tworzenia wspólnoty znaczeń wokół określonych treści muzycznych. Po drugie, muzyka zaspokaja potrzebę komunikowania się wzajemnego ludzi, często ponad podziałami społecznymi. Jak mawiał Jerzy Waldorff, „muzyka łagodzi obyczaje”. Jest ona zatem naturalnym medium międzyludzkiej komunikacji, umożliwiając przekraczanie 
kulturowych i społecznych barier. Po trzecie, muzyka może zaspokajać też indywidualne potrzeby wewnętrzne, $\mathrm{w}$ tym potrzeby emocjonalne, działając jak przysłowiowy „balsam na duszę”, służąc jako element odskoczni, rozrywki, terapii, poprawy nastroju. Przykładem może być tutaj muzykoterapia, która „leczy dźwiękiem”, jak również wszelkie formy muzycznego eskapizmu. Po czwarte, muzyka służyć może do celów znacznie bardziej zinstytucjonalizowanych, takich jak życie polityczne, edukacyjne, religijne czy ekonomiczne. W tym sensie można mówić o funkcji politycznej muzyki, w której realizowane są cele marketingowe, promocyjne, perswazyjne czy mobilizacyjne. Doskonałym przykładem są kampanie wyborcze, w których „używa się” muzyki dla celów zjednania elektoratu. Innym wymiarem funkcjonalności muzyki jest jej niesłychanie ważna rola edukacyjna. W tym sensie muzyka uczy i kształtuje społeczeństwo. Podobnie funkcjonalna względem społeczeństwa jest także muzyka w aspekcie religijnym, zaspokajając zinstytucjonalizowaną potrzebę budowania wspólnoty religijnej i zapośredniczając kontakt $\mathrm{z}$ istotą wyższą. I na koniec, muzyka pełni też istotną rolę w systemie ekonomicznym, stając się ważnym elementem przemysłu muzycznego i zaspokajając konsumpcyjne potrzeby społeczeństwa.

Jak już wspomniałam, są to jedynie skrótowe uwagi na temat funkcjonalnych aspektów muzyki w społeczeństwie, które w całości nie mieszczą się w ramach niniejszego opracowania. Refleksje te jednak stanowią doskonałe podsumowanie dotychczasowych rozważań nad społecznym charakterem muzyki. Sztuka dźwięków jest bowiem immanentnie powiązana z procesem zaspokajania najróżniejszych ludzkich potrzeb, stanowiąc integralny element życia społeczno-muzycznego.

\section{Refleksje końcowe}

Patrząc na wszystkie powyżej wymienione aspekty społecznego wymiaru muzyki, można powiedzieć, że muzyka jest formą praktyki społecznej. To w niej bowiem ogniskują się czynniki zarówno mikro-, jak i makrostrukturalne, determinując charakter kultury muzycznej danego społeczeństwa. To w niej także dochodzi do reprodukowania systemu społecznego przez wzajemne sprzężenia pomiędzy strukturalnym i konstruktywistycznym wymiarem ludzkich działań nakierowanych na muzykę. Praktyka muzyczna łączy się bowiem zarówno z elementem subiektywnych działań ludzkich, w których zachodzi proces nadawania znaczeń muzycznym treściom, jak i wiąże się z elementem obiektywnym, odnoszącym się do strukturalne- 
go wymiaru życia społecznego. Tym samym możliwe staje się tworzenie i reprodukowanie na nowo muzycznej płaszczyzny ludzkiej aktywności. Równocześnie muzyka stanowi element wytwarzania, jak i zapośredniczania społeczno-muzycznych praktyk.

Podsumowując dotychczasowe rozważania należy na koniec raz jeszcze podkreślić, iż muzyka jest „bytem społecznym” ze względu na szereg czynników, które zostały tu wspomniane. Świadczą one dobitnie o społecznym charakterze muzyki. Niniejszy tekst miał na celu ukazanie najważniejszych cech, stanowiąc jedynie zalążek dla dalszej naukowej debaty nad społecznym wymiarem muzyki.

\section{Bibliografia}

Arystoteles (1964), Polityka $z$ dodaniem pseudo-Arystotelesowskiej ekonomiki, Warszawa.

Bloom A. (1987), Umysł zamknięty, Poznań.

Bourdieu P. (2005), Dystynkcja. Społeczna krytyka władzy sadzenia, Warszawa.

Etzkorn K.P. (1964), Georg Simmel and the Sociology of Music, "Social Forces", nr 43(1), s. 101-107.

Etzkorn K.P. (red.) (1973), Music and Society. The Later Writings of Paul Honigsheim, Londyn, Sydney, Toronto, Nowy Jork.

Frith S. (2011), Sceniczne rytuały. O wartości muzyki popularnej, Kraków.

Griswold W. (2013), Socjologia kultury. Kultury i społeczeństwa w zmieniającym się świecie, Warszawa.

Grzeliński A. (2012), Prawda i znaczenie dzieła sztuki jako problem estetyki, [w:] A. Nowak (red.), Dzieło muzyczne jako znak, Bydgoszcz. s. 9-27.

Jabłońska B. (2014), Socjologia muzyki, Warszawa.

Kaesler D. (2010), Weber. Życie i dzieło, Warszawa.

Kłoskowska A. (1991), Encyklopedia Kultury Polskiej XX wieku. Pojęcia i problemy wiedzy o kulturze, Wrocław.

Kłoskowska A. (1972), Społeczne ramy kultury. Monografia socjologiczna, Warszawa

Kofin E. (2012), Muzyka wokót nas. Studium przeobrażeń recepcji muzyki w dobie elektronicznych środków jej przekazywania, Wrocław

Ossowska M. (2007), Funkcjonowanie norm w życiu społecznym, [w:] P. Sztompka, M. Kucia (red.), Socjologia. Lektury, Kraków, s. 299-305.

Ossowski S. (1966), U podstaw estetyki, Warszawa.

Paderewski I. J. (1984), Pamiętniki, Kraków.

Peterson R. (1978), The Production of Cultural Change: The Case of Contemporary Country Music, "Social Research", t. 45, nr 2, s. 292-314. 
Pietras K. (2015), Odbiorca oddziałuje na wykonawcę, [w:] J. Kaleńska-Rodzaj, R. Lawendowski (red.), Psychologia muzyki. Pomiędzy wykonawca a odbiorca, Gdańsk, s. 41-55.

Platon (1958), Państwo z dodaniem siedmiu ksiag Prawa, Warszawa.

Schütz A. (2008), Wspólne tworzenie muzyki. Studium relacji społecznych, [w:] idem, O wielości światów. Szkice z socjologii fenomenologicznej, Kraków, s. 225-239.

Silbermann A. (1963), The Sociology of Music, Londyn.

Sorokin P.A. (1991), Social and Cultural Dynamics: a Study of Change in Major Systems of Art, Truth, Ethics, Law and Social Relationships, New Brunswick, Londyn.

Stockfelt O. (2010), Odpowiednie sposoby stuchania, [w:] Ch. Cox, D. Warner, Kultura dźwięku. Teksty o muzyce nowoczesnej, Gdańsk, s. 120-126.

Stróżewski W. (1983), Dialektyka twórczości, Kraków.

Sztompka P. (2002), Socjologia. Analiza społeczeństwa, Kraków.

Szymanowski K. (1949), Wychowawcza rola kultury muzycznej w społeczeństwie, Kraków.

Turley A. C. (2001), Max Weber and the Sociology of Music, "Sociological Forum", nr 16/4, s. 633-653.

Weber M. (2009), The Rational and Social Foundations of Music, Mansfield.

Weber M. (2013), Racjonalne i socjologiczne podstawy muzyki (fragmenty), „Stan Rzeczy”, nr 1(4), s. 11-26.

\section{SUMMARY}

\section{On the Social Character of Music. A Sociological Draft}

The purpose of the article is to discuss the social features of music in a sociological perspective. The authoress points to the strong links between music, and the social life of people. She also discusses the social determinants of the art of music, using selected theoretical concepts in sociology. The text is divided according to the six basic aspects of the social character of music, such as: music as a symbolic culture and a set of meanings; music as a social relationship; music as a social context and normative rules; music as an element of social structure; music as a social change; and music as a functional element of society.

KEYWORDS: music, musical practices, social change, social functions of music, society, sociology of music 